\title{
Nacionālo partizānu grupu veidošanās un darbība Ziemeḷrietumvidzemē 1944. gada rudenī - 1945. gadā
}

\author{
Formation and Activities of Groups of National Partisans in \\ Northwestern Vidzeme from the Autumn of 1944 to the End of 1945
}

\author{
Reinis Ratnieks, Mg. hist. \\ Latvijas Universitātes Vēstures un filozofijas fakultāte \\ Aspazijas bulvāris 5, Rīga, LV-1050 \\ E-pasts: ratnieksr@gmail.com
}

Līdzīgi kā citviet Latvijā, arī Ziemel̦rietumvidzemēên pēc padomju okupācijas režìma veiktās mobilizācijas Sarkanajā armijā un represijām veidojās bruṇotas pretošanās grupas mežos, lai cīnītos pret PSRS okupāciju. Atškirībā no citiem Latvijas reǵioniem, tur neizveidojās spēcīga pretošanās kustība un nedaudzās partizānu grupas lielākoties ieturēja nogaidošu taktiku, cerot uz Rietumvalstu militāru atbalstu.

Atslēgvārdi: pretošanās kustība, nacionālie partizāni, padomju okupācija, mobilizācija, represijas, Ziemel̦rietumvidzeme.

Just like all over Latvia, the Soviet-decreed mobilization and repressions resulted in formation of armed resistance groups in Northwestern Vidzeme's forests to fight against the Soviet occupation. In comparison to other regions of Latvia, the armed resistance did not become as strong and the few partisan groups mostly lived quietly hoping for a military assistance from the West.

Keywords: Resistance movement, national partisans, Soviet occupation, mobilization, repressions, Northwestern Vidzeme.

Tāpat kā pārējā Latvijas teritorijā, arī Ziemeḷrietumvidzemē tūlìt pēc padomju okupācijas atjaunošanas tika uzsākta vietējo iedzīvotāju mobilizācija Sarkanajā armijā, kā arī padomju režīmam nevēlamo un aizdomīgo personu aresti. Tas izraisīja daudzu cilvēku pāriešanu nelegālā stāvoklī un vēlāk nacionālo partizānu grupu veidošanos cīṇai pret okupāciju. Liekot cerības uz Rietumvalstu drīzu palīdzību cīṇā pret okupācijas režīmu, partizānu grupas īstenoja uzbrukumus režīma vietējiem pārstāvjiem vai arī izvēlējās nogaidīt līdz jauna kara sākumam. Rakstā ir analizēti šie notikumi Ziemel̦rietumvidzemē, pievēršot uzmanību bruṇoto nelegālistu un partizānu grupu izveidei, darbībai un tās rezultātiem, kā arī okupācijas režīma pretdarbībai. No iepriekšminētā 
izriet mērķis analizēt nacionālo partizānu grupu veidošanās gaitu un darbības ìpatnības Ziemeḷrietumvidzemē laikā no otrreizējās padomju okupācijas sākuma 1944. gada rudenī līdz 1945. gada nogalei.

Heinrihs Strods, kurš pirmais sāka šīs tēmas zinātnisku izpēti, runājot par partizānu kustības izveidošanos, norāda uz vairākiem cēloṇiem - Latvijas valstiskuma zaudēšanu, padomju okupācijas režīma represīvo saimniecisko un kulturālo politiku, mobilizāciju Sarkanajā armijā u. c. ${ }^{2}$ Šajā ziṇā būtu jānodala noteicošie cēloṇi, kas tieši izraisīja cilvēku nonākšanu pretestības cīnītāju rindās, un tie cēloni, kas motivēja pretoties režìmam vai atbalstīt nacionālos partizānus, bet paši par sevi lielākoties nelika tieši iesaistīties bruṇotajā pretestībā. Piemēram, Zigmārs Turčinskis savā pētijjumā par partizānu grupu darbību Valkas apriņ̧̧ī un Alūksnes apriṇk,a rietumu dạ̄ā skaidri parādījis bruņotās pretestības rašanās tiešos cēloṇus šajā reǵionā, proti, Latvijas iedzīvotāju mobilizāciju Sarkanajā armijā un masveida represijas, kas deva grūdienu cilvēku pārejai nelegālā stāvoklī un pretošanās sākumam. ${ }^{3}$

1945. gads bija nacionālo partizānu darbības augstākais punkts. Laikā, kad okupācijas režìms vēl nebija paguvis nostiprināties, daudzos Latvijas pagastos partizāni bija faktiskie situācijas noteicēji. 1945. gada vasarā sadursmes starp partizāniem un okupācijas varas pārstāvjiem notika ik dienu. Abrenes apriṇkī partizānu darbības dēl ap $60 \%$ ciema padomju tika iznīcinātas vai nespēja uzsākt darbu. ${ }^{4}$ Z. Turčinskis norāda, ka laikā no 1945. gada 15. maija līdz 16. novembrim partizāni Ziemeḷvidzemē bija īslaicīgi ieņēmuši deviṇu pagastu centrus, turklāt divus no tiem atkārtoti. Partizānu spiediens šajā reǵionā bija tik liels, ka Alsviķos starp čeku un partizāniem pat tika parakstīta vienošanās par uguns pārtraukšanu no 1945. gada 29. septembra lìdz 9. oktobrim - tā ir unikāla partizānu kara epizode visas Baltijas mērogā. ${ }^{5}$
Tā kā čeka nespēja gūt nozīmīgus panākumus cīnā ar partizāniem, tā, sākot ar 1945. gada rudeni, partizānu apkarošanā iesaistītos spēkus pārstrukturēja un koncentrēja partizānu darbības pārṇemtākajos novados, un apvienojumā ar ziemas tuvošanos tas sāka dot rezultātus. Izmantojot partizānu mobilitātes samazināšanos, čekisti spēja veikt veiksmīgus triecienus pa grupām, kuras bija sākušas ieziemoties. Lai vājinātu brunoto pretestības kustību, tika izvērsta arī legalizācijas kampaṇa, aicinot partizānus pārtraukt cīṇu un nodot ieročus apmaiṇā pret amnestiju. Plašākais uzsaukums legalizēties ar Latvijas PSR iekšlietu tautas komisāra Augusta Eglīša parakstu tika publicēts 1945. gada 12. septembra "Cīnas" numurā. ${ }^{6}$

Latvijas nacionālo partizānu vēstures izpētes līmenis joprojām uzskatāms par samērā zemu, jo ir maz vēsturnieku, kuri zinātniski pētītu partizānu darbību konkrētos reǵionos. Pašlaik nopietnāki pētījumi ir veikti par Vidzemes ziemel̦u daḷ $\mathrm{u}^{7}$ un arī par Bauskas apriņ, ,i, ${ }^{8}$ taču pilnvērtīgai kopainas noskaidrošanai ar to ir par maz, tāpēc vispārējus secinājumus joprojām nākas izdarìt galvenokārt pēc padomju okupācijas varas iestāžu apkopojošiem dokumentiem un salīdzinot atseviškus zināmos faktus par partizānu darbību dažādos reǵionos.

Rakstā aplūkota līdz šim Latvijas nacionālo partizānu pētniecībā gandrīz neapskatīta teritorija. Z. Turčinskis ir pieskāries dažiem notikumiem Ziemeḷrietumvidzemē saistībā ar Kārḷa Mūsiṇa grupas pārziemošanu Rozēnu pagastā 1946.-1947. gada ziemā (grupa darbojās Valkas apriṇkīi) un grupas veiktajām pārtikas sagādes akcijām Rūjienas rajonā 1952. gadā. ${ }^{9}$ Neskaitot šīs epizodes, reǵiona partizānu darbība Latvijas historiogrāfijā vispār nav skatīta.

Minēto iemeslu dēḷ pētījums ir pilnībā balstīts uz pirmavotiem. Pamatā izmantotas Latvijas Nacionālā arhīva Latvijas Valsts arhīvā pieejamās Latvijas PSR Valsts 
drošības komitejas (VDK) krimināllietas, kurās tiesāti pretošanās kustības dalībnieki un viṇu atbalstītāji. ${ }^{10}$ Šajās krimināllietās ietvertajos apsūdzēto personu pratināšanas protokolos, dažādās izzin̄ās u. c. dokumentos ir pieejams plašākais faktu materiāls par nacionālo partizānu darbību, kas, kritiski izvērtēts, sniedz visumā labu informāciju.

Otrs nozīmīgākais pētījumā izmantotais avots ir nacionālo partizānu un to darbības uzskaites kartotēka Latvijas Nacionālajā arhīvā. ${ }^{11}$ Kartotēkā pieejamas īsas ziṇas par nacionālajiem partizāniem, viṇu darbību, atbalstītājiem u. c. informācija, kas bija svarīga čekai ${ }^{12}$ partizānu apkarošanā, taču lielākā vērtība ir unikālā informācija par pasākumiem, kuri vērsti pret partizāniem, tas ir, par aǵentūras lietu veidošanu, operatīvajiem plāniem un veiktajām kaujas operācijām, - tā sniedz dziḷāku ieskatu čekas cīṇā ar nacionālo bruṇoto pagrīdi.

Trešais būtiskākais avots, kas izmantots pētījuma tapšanā, ir atmiņas, kuras rūpīgi salīdzinātas ar dokumentiem un var sniegt nekur citur neatrodamu informāciju par notikumiem, cilvēku motivāciju, personīgajām īpašībām u. tml. Nemot vērā, ka darbs pie pētījuma tika uzsākts 2015. gada nogalē, kad jau tikpat kā vairs nebija dzīvi laikabiedri, kas saistīti ar aprakstītajiem notikumiem, informācija raksta autora veiktajās intervijās lielākoties iegūta no šo cilvēku pēctečiem. Nozīmīgus faktus par aprakstītajiem notikumiem izdevās uzzināt arī no publicētajiem atmiṇu krājumiem. ${ }^{13}$

\section{Personu pāriešana nelegālā stāvoklī pēc mobilizācijas Sarkanajā armijā un arestiem Ziemeḷrietumvidzemē 1944. gada septembrī - 1945. gada sākumā}

Pēc padomju okupācijas atjaunošanas Valmieras apriṇkīi notika plaša cilvēku pāreja nelegālā stāvoklī, to izraisīja pretlikumīgais iesaukums Sarkanajā armijā, kā arī "naidīgo elementu" aresti, kas radīja būtiskus priekšnosacījumus bruṇotās pretošanās kustības izveidei.

Valmieras apriņķa kara komisariāts kopš 1944. gada 30. septembra, kad vēl daḷa apriṇķa atradās vācu armijas kontrolē, veica tā teritorijā dzīvojošo cilvēku uzskaiti un 1908.-1926. gadā dzimušos vīriešus iesauca Sarkanajā armijā. ${ }^{14}$ Izvērstās mobilizācijas rezultātā līdz 1945. gada 1. janvārim tika iesaukti 2643 apriņķa iedzīvotāji tas bija samērā daudz uz pārējo Latvijas apriṇku fona, kuri atradās PSRS kontrolē.

Vienlaikus pēc mobilizācijas sākuma apriṇkī norisinājās gan dezertēšana no Sarkanās armijas, gan izvairīšanās no mobilizācijas. Dezertieru skaits bija visai neliels, proti, līdz 1945. gada 1. janvārim no Sarkanās armijas bija dezertējuši tikai 33 Valmieras apriṇķa iedzivotāji. ${ }^{15}$ Ziemel̦rietumvidzemē no Sarkanās armijas lìdz 1945. gada 1. janvārim bija dezertējuši vismaz seši cilvēki. Tajā pašā laikā 21 persona no pētījumā aplūkotajiem nelegālistiem bija izvairījusies no iesaukuma - tas nozīmē, ka visā Valmieras apriṇḳi šis skaits noteikti bija lielāks par dezertieru skaitu. Ziemeḷrietumvidzemē pret dienestu Sarkanajā armijā nelabvēlīgi noskaņotie un drosmīgākie lielākoties vienkārši izvairījās no dienesta, neejot uz kara komisariātiem pēc okupācijas atsākšanās un uzsākot nelegālistu dzīvi.

Pēc padomju reokupācijas nelegālā stāvoklī pārgāja arī daudzi bijušie vācu okupācijas laika policisti, aizsargi un leǵionāri. Vietējo iedzivotāju aizturēšana un aresti Valmieras apriṇkīi norisinājās jau kopš 1944. gada rudens, kad laikā no oktobra līdz 1945. gada 1. janvārim apriņk̦ī bija aizturētas 310 "aizdomīgas personas", no kurām lielākā daḷa tika arestētas un tiesātas. ${ }^{16}$

Represijas uzn̄ēma jaunus apgriezienus pēc 1945. gada 11. janvārī izdotās PSRS 
Iekšlietu Tautas komisariāta (IeTK) pavēles Nr. 0016, ar kuru tika uzdots arestēt pretpadomju grupu dalībniekus un dažādu "fašistisko" organizāciju bijušos dalībniekus, Vācijas armijas militārpersonas un "aizdomīgos elementus". ${ }^{17}$ Šì pavēle bija plaši interpretējama un pavēra iespējas arestiem bez īpaša pamatojuma. Līdz ar to masveidā nelegālā stāvoklī pārgāja bijušie leg̣ionāri, policisti, aizsargi un citas iedzìvotāju kategorijas, kuras jutās apdraudētas.

Uzskatāms piemērs šìm represijām bija notikumi Valmieras apriņ̧̧a Idus pagastā, kur 1945. gada janvāra nogalē norisinājās bijušo aizsargu aresti. Piemēram, pēc Vērša ciema iedzìvotājas Martas Grīnvaldes atmin̄ām, kādas nakts laikā tika arestēti vismaz devini bijušie aizsargi. ${ }^{18}$ Arestu rezultātā Ternejas pagastā nelegālā stāvoklī pārgāja arī Rūjienas vidusskolas fizkultūras skolotājs Eduards Čoka, kurš turpmākos mēnešus aktīvi darbojās partizānu grupu veidošanā vietējā apkārtnē. ${ }^{19}$

Minēto represiju ietekmē Ziemeḷrietumvidzemē nelegālā stāvoklī pārgāja un aplūkotajās bruṇotajās grupās apvienojās aptuveni 30 bijušo leǵionāru, policistu un aizsargu. Ârpus šìm grupām konkrētajai kategorijai piederīgo slēpušos personu skaits lēšams kā vēl lielāks. Faktiski šādas represijas veicināja spēcīgākas bruṇotās pretošanās kustības veidošanos, jo mežos nonāca vīri ar militāru pieredzi un motivāciju pretoties. Piemēram, 1945. gadā Ziemeḷrietumvidzemē izveidojās Viḷa Skujiṇa, Pētera Dauguḷa un E. Čokas partizānu grupas, kuru līderi bija dienējuši Vācijas militārajos formējumos, turklāt šajās grupās bija liels bijušo policistu un aizsargu ippatsvars.

Ziemeḷrietumvidzemē bruṇotās nelegālistu grupās apvienojušos cilvēku skaits bija neliels un, pēc aptuvenām aplēsēm, nepārsniedza 100 cilvēku, līdz ar to partizānu kustība tur nebija tik intensīva kā citviet Latvijā, piemēram, Valkas apriņkīi. Z. Turčinskis izvirza skaidrojumu, ka 1944. gada augustā karadarbības fronte gandrīz uz mēnesi apstājās Gaujas līnijā - tas ḷāva no Rietumvidzemes izbraukt daudziem policistiem, ierēdniem, lielsaimniekiem un citām potenciāli represējamām personām, līdz ar to potenciālo partizānu dzīvā spēka bāze tur bija mazāka. ${ }^{20}$

\section{Partizānu grupu veidošanās Rozēnu un Mazsalacas pagastā}

Laikā no 1944. gada oktobra līdz 1945. gada janvārim Rozēnu pagastā izveidojās trīs bruṇotas nelegālistu grupas, kuras sastāvēja gan no personām, kas bija izvairījušās no iesaukuma Sarkanajā armijā pēc izsludinātā iesaukuma 1944. gada 16. oktobrī, Sarkanās armijas dezertieriem, gan no bijušajiem aizsargiem un policistiem, kuri glābās no iespējamām represijām. ${ }^{21}$

Divas šādas grupas sešu un septiņu cilvēku sastāvā ierīkoja bunkurus Zābaku purvā. Lai arī formālu komandieru tām nebija, čekas dokumentos tās tika nosauktas par Ernesta Vilņa un Arnolda Liepiņa "bandām". Abas grupas dzīvoja mežā tuvu viena otrai un uzturēja ciešus savstarpējos sakarus. Nekāda pretdarbība okupācijas režīmam nebija plānota, jo galvenās cerības tika liktas uz gaidīto karu starp PSRS un Rietumvalstīm - tas dotu iespēju brīvi atgriezties mājās.

Kopumā šo grupu dzive Zābaku purva mežā bija bez sevišķiem satricinājumiem. Draudi sadurties ar pretinieka spēkiem radās 1945. gada 12. februārī, kad kāds no E. Viḷna grupas vīriem pamanīja tuvojošos iznīcinātāju k̦ēdi. Grupas dalībnieki paguva pamest bunkuru un, pa ceḷam pabrīdinājuši otru grupu, devās prom un iekārtojās jaunā vietā dziḷāk mežā. ${ }^{22}$

Abas grupas pastāvīgi atradās IeTK Valmieras apriṇka daḷas uzmanības lokā. 
1945. gada 12. jūnijā tika izstrādāts plāns grupu likvidācijai aǵentūras lietas Bolotnije ietvaros. ${ }^{23} 19$. jūnijā Rozēnu pagastā tika organizēta viensētu pārmeklēšana, taču, tā kā nelegālisti mājās neslēpās, čekisti spēja vien aizturēt septinus "bandītu" atbalstītājus. ${ }^{24}$ Čekisti izdarīja spiedienu uz mežā dzīvojošo radiniekiem, vairākkārt vinus aizturot un pieprasot izvest radus no meža. ${ }^{25}$ Tas, kā arī kara beigas un motivācijas trūkums tālākai meža dzīvei deva rezultātus, lìdz ar to no 1945. gada jūnija sākās pakāpeniska grupu sadalī̌̌anās un legalizācija. Vēlāk no 12 personām 1945. gada 25.-30. augustā legalizējās astonas. ${ }^{26}$ Mežos palikušie neticēja, ka legalizējoties netiks represēti, tāpēc turpināja slēpties. $^{27}$

Trešā nelegālistu grupa Rozēnu pagastā izveidojās 1945. gada janvārī-februārī no četriem vietējiem Sarkanās armijas dezertieriem un nelegālista, kurš bija izvairījies no iesaukuma Sarkanajā armijā. Šì grupa iekārtojās izbūvētā zemnīcā Salacas krastā, bet arī neplānoja uzbrukt padomju režīmam. Piesardzības nolūkos zemnīcas apkārtnē tika izliktas kājnieku mīnas. ${ }^{28}$ Par galvenajiem drošības pasākumiem šie nelegālisti gan nebija padomājuši, jo grupas dalîbnieka Jāna Ilus tēva nopratināšanas laikā 3. martā čekistiem izdevās noskaidrot grupas slēpšanās vietu. ${ }^{29}$ Tā kā J. Ilus bija neapdomīgi pastāstījis tēvam par savu slēpšanās vietu, grupas atklāšana bija vairs tikai laika jautājums. Vakarā no 4. uz 5. martu tika organizēta čekas operācija, kuras rezultātā visi pieci grupas locekḷi tika sagūstīti, viṇi arī neizrādīja nekādu pretošanos. ${ }^{30}$

Blakus esošajā Mazsalacas pagastā no apkārtnes policistiem izveidojās partizānu grupa, ko vadīja Latvijas armijas kapteinis P. Daugulis, kurš vācu okupācijas laikā bija Mazsalacas komandants, kā arī 319. policijas bataljona rotas komandieris. Pēc tam, kad frontes līnija šḳērsoja Mazsalacu
1944. gada septembra beigās, P. Daugulis sāka slēpties, vienlaicīgi apvienojot vietējos nelegālistus, lai izveidotu partizānu vienību, kas Rietumvalstu un PSRS kara gadījumā uzbruktu padomju okupācijas varai. Interesanti, ka P. Daugulis plānoja partizānu karu jau kopš 1943. gada, aicinot savas rotas karavīrus no Mazsalacas pagasta pēc vācu armijas atkāpšanās uzsākt partizānu gaitas dzimtajā apvidū. ${ }^{31}$ Gaidot karu, šì grupa klusi dzīvoja purvainajos mežos Igaunijas pierobežā un izvairījās no jebkādiem uzbrukumiem okupācijas režīmam. Līdz 1944. gada decembrim grupas locekḷu skaits pieauga līdz 10 cilvēkiem.

Arī šīs grupas pastāvēšanas laiks bija samērā īss. 6. februārī IeTK Valmieras apringka dal̦a apstiprināja plānu "Dauguḷa bandas atklāšanai un likvidācijai”, tā neapšaubāma sastāvdaḷa bija partizānu radinieku izmantošana, lai aicinātu tos legalizēties. ${ }^{32}$ Šāda apstākḷa dēḷ 1945. gada janvārī grupai jau bija pievienojies grupas dalībnieka Edgara Kažoka tēvs Tenis Kažoks, kuram čeka bija pavēlējusi izvest dēlu no meža. ${ }^{33}$ Tuvojoties pavasarim, grupa pamazām sadalījās sīkākās daḷās, partizāni apmetās tuvāk savām mājām. Pakāpeniski čeka aizvien vairāk sāka tramdīt pārējo grupas locekḷu radiniekus, tāpēc, lai represijas neskartu vinu ǵimenes, partizāni 1945. gada nogalē pēc savstarpējas vienošanās atgriezās mājās un legalizējās līdz 1946. gada janvārim. Pats P. Daugulis turpināja slēpties viens pats, bet izspiegošanas vai nodevības dēḷ čekas operācijā 1945. gada 26. decembrī tika sagūstīts netālu no agrākās grupas slēpšanās vietas un vēlāk notiesāts ar nāvessodu. ${ }^{34}$

Partizānu grupu ātrā izjukšana Rozēnu un Mazsalacas pagastā iezīmēja būtisku problēmu - partizānu grupu darbība viņu māju tuvumā nebija iespējama, nepakḷaujot represijām radiniekus. Tā kā jauns karš nebija sācies, partizāni un nelegālisti, kuriem bija iespēja legalizēties un mierīgi dzīvot tālāk, pieteicās varas iestādēm. 
Skujiṇa partizānu grupas

izveidošanās un darbība 1944. gada rudenī - 1945. gada vasarā

Šajā laikā aktīiākā nacionālo partizānu grupa Ziemeḷrietumvidzemē izveidojās Limbažu apkaimē. Savās mājās Katvaru pagasta "Mežniekos" slēpās bijušais policists V. Skujiņš kopā ar brāliem Elmāru un Albertu, kā arī savu kaimiṇu Ziedoni Muciņu, kurš bija izvairījies no iesaukuma Sarkanajā armijā. Četrotne pēc Valmieras aprinkka nonākšanas Sarkanās armijas kontrolē sāka slēpties Skujiṇu piemājas šḳūnī izraktā zemnīcā.

Grupas aktivizēšanās notika Skujinu kaiminu nodevības dẹl. Blakus mājās dzīvoja padomju aktīviste Zelma Kalniņa, kura 1945. gada pavasarī ievēroja, ka no "Mežniekiem", kur dzīvoja it kā tikai Augusts Skujiṇš ar sievu, loti ātri tiek izvestas mēslu kaudzes, un tas radīja aizdomas par vēl kādu darbaroku klātesamību. Z. Kalniņa par to pazinoja Katvaru pagasta partorgam Jānim Voldiņam, kurš kopā ar trīs iznīcinātājiem 1945. gada 2. maijā devās uz "Mežniekiem" tvarstīt nelegālus. ${ }^{35}$

Atstājis sargposteñus pie ceḷa uz "Mežniekiem", J. Voldiņš ar iznīcinātāju Jēkabu Vīinnu devās pārmeklēt mājas. Ieraudzījis tvarstītājus, Skujinuu tēvs paguva brīdināt šķūnī mìtošos nelegālus, kuri atklāja uguni. Apšaudes laikā Skujiņa grupa atkāpās mežā, savukārt J. Voldiņš un J. Vītiņš tai sekoja. Tālākajā kaujā mežā abus vajātājus Skujiṇa grupa nošāva, savukārt viṇu lịķus pēc trīs dienām purva akacī atrada iekšlietu karaspēka 36. motostrēlnieku pulka karavīri, kuri pārmeklēja apkārtni. Pēc čekas papildspēku ierašanās brāḷ Skujiṇu vecāki, zinādami, kas viniiem draud par dēlu slēpšanu, māju pirtināa izdarīja pašnāvību, uzspridzinoties ar rokasgranātu. ${ }^{36}$

Šie notikumi motivēja Skujiṇa grupu uzsākt aktīvas atriebības akcijas pret vietējām padomju varas iestādēm un to atbalstîtājiem, vienlaikus cerot, ka drīz sāksies karš starp Rietumvalstīm un PSRS. ${ }^{37}$ Līdz ar to partizānu grupa pamazām pulcēja apkārtnes nelegālistus, gādāja bruṇojumu un munīciju, kā arī ierīkoja jaunas slēpšanās vietas. Jūnija sākumā grupa palielinājās līdz sešiem cilvēkiem un drīz vien sāka pirmos uzbrukumus okupācijas režīma pārstāvjiem Katvaru pagastā un tā apkārtnē.

Pirmo akciju pret okupācijas režīmu Skujiña grupa centās īstenot 18. jūnijā, kad Katvaru skolā bija plānots svinīgs pasākums par godu Latvijas PSR piecgadei. Lai izbojātu okupantu svētkus, kāds no grupas dalībniekiem mīnēja skolas ārdurvis, taču partizāna darbošanās ap durvīm tika pamanīta, tādēl nācās priekšlaicīgi uzspridzināt izliktās mīnas. Sekojošās čekas operācijas laikā tika aizturēti divi grupas atbalstītāji. ${ }^{38}$

Pēc neliela klusuma perioda tika veikts uzbrukums Umurgas izpildkomitejas priekšsēdētājam un Limbažu tautas tiesas piesēdētājam Antonam Prauliṇam, kurš bija iesaistìts padomju režìma represīvo lēmumu ìstenošanā. 15. augustā V. Skujiņš ierīkoja slēpni netālu no vina mājām Umurgas pagastā pa ceḷam uz Limbažiem. A. Praulinuu izdevās sagaidīt ap plkst. 09.00, kad izpildkomitejas priekšsēdētājs kopā ar meitu devās uz Limbažiem. Lai apturētu viña pajūgu, V. Skujiņ̧̌ nostājās priekšã uz cel̦a, taču A. Prauliņš neapstājās, un V. Skujiņš atklāja uguni, nogalinot aktīvistu un viegli ievainojot viņa meitu, kurai izdevās pārṇemt vadību un aizbraukt līdz Limbažiem. ${ }^{39}$

Vietējo aktīvistu iznīcināšanā aktīvi iesaistijāas abi V. Skujiña jaunākie brāḷi E. Skujiņš un A. Skujiņšs. Pirmais abu mērkis bija iznīcinātājs Jāzeps Kandavnieks, kurš dzìvoja uz Pāles un Katvaru pagasta robežas un kuram jau 1945. gada jūlijā vienreiz bija izdevies izsprukt no Skujiņu uzbrukuma. Toreiz iznīcinātājs tika apšaudīts, braucot pa ceḷu ar velosipēdu. Visticamāk, 
šĩ uzbrukuma sakarā 30. jūlijā Skujiṇa grupas partizānu meklēšanai Pociema pagasta mežos tika novirzìta Valsts drošības tautas komisariāta operatīvā grupa iekšlietu karaspēka karavīru un iznīcinātāju sastāvā, bet partizānu meklēšana beidzās bez rezultātiem. ${ }^{40}$ Nākamajā reizē 17 . augusta rītā abi grupas komandiera brāli noslēpās mežā netālu no viṇa mājām "Ludiṇkroga" Pāles pagastā, lai sagaidītu J. Kandavnieku dodamies pēc ganībās atstātā zirga. Pēc iznīcinātāja aizturēšanas partizāni viṇu ieveda dziḷāk mežā un nošāva. ${ }^{41}$

Abi brāḷi drīz vien veica nākamo uzbrukumu, kas tika vērsts pret vinu kaimiṇu un iznīcinātāju Kārli Kalniṇu, kurš bija iesaistīts Skujiṇu aizturēšanas mēgeinājumā 1945. gada 2. maijā. Nolēmuši atriebties par nodevību, Skujiṇi 1. septembrī sagaidīja K. Kalniṇu pie Līdumnieku mājām un vinu nošāva. ${ }^{42}$

Lìdz ar 1945. gada vasaru Skujina grupa bija uzsākusi uzbrukumus padomju režīma aktīvistiem un nepilna mēneša laikā nogalināja vienu padomju aktīvistu un divus iznīcinātājus. Valmieras apriņ̧̧a komitejas kara dalias atbildīgais Rozenbergs savā atskaitē 1945. gada septembrī konstatēja, ka IeTK apriņ̧̧a daḷa nespēj tikt galā ar Skujiņa grupas uzbrukumiem, kuri ir nopietni demoralizējuši vietējos iznīcinātājus. ${ }^{43}$ Spriežot pēc dokumentiem, čeka nebija veikusi nekādus nopietnus pasākumus Skujiņa grupas iznīcināšanai. Aǵentūras lieta pret to tika vērsta tikai 1945 . gada oktobra otrajā pusē. ${ }^{44}$

\section{Eduarda Čokas darbība partizānu grupu veidošanā}

Rūjienas apkārtnē cilvēku pāriešana nelegālā stāvoklī pastiprinājās līdz ar 1945. gada janvāra arestiem. Slēpties sāka arī Rūjienas vidusskolas fizkultūras skolotājs un Latviešu leǵiona 19. grenadieru divīzijas leitnants E. Čoka, kurš ievainots bija atgriezies mājās Ternejas pagastā vēl pirms fronte šķērsoja Valmieras apriņ̧̧i un palicis tur līdz Sarkanās armijas ienākšanai Vidzemē. E. Čoku sākt slēpties pamudināja uzaicinājums ierasties uz nopratināšanu IeTK. ${ }^{45}$

Pēc pārejas nelegālā stāvoklī E. Čoka sāka apzināt apkārtnes nelegālistus un apvienot grupā. Grupas sastāvs gan bija nepastāvīgs, taču neilgu brīdi jūnijā tās dalībnieku skaits bija sasniedzis 16 cilvēkus, kas bija l,oti daudz šim reǵionam. Maijā grupa nobāzējās Mazsalacas pagasta Rūḳu mežā, kur partizāni izveidoja sakarus ar vietējo mežsargu Eduardu Vīḳi. ${ }^{46}$ E. Čokas grupai bija arī pieejama informācija par plānotajām čekas operācijām vietējā apkaimē, pateicoties tam, ka grupas atbalstītāja M. Grīnvalde strādāja par telefonisti netālajā Idus pagasta pasta un telefona centrālē "Vērsis". ${ }^{47}$

Par mērki tika izvirzīta gatavošanās cīnai pret padomju režīmu, tajā pašā laikā E. Čoka vēlējās atturēties no bruṇotām akcijām, kamēr nav sācies Rietumvalstu uzbrukums PSRS. Līdz tam brīdim tika pieḷauta pretošanās nevardarbīgā veidā. Tā 15. maijā E. Čoka kopā ar partizāniem Kārli Bērziņu, Jāni Rezgali un Ernestu Blāḳi Rūjienā, netālu no Sv. Bērtuḷa luterāṇu baznīcas, izkāra Latvijas karogu. ${ }^{48}$

Paralēli apkaimes nelegālistu apvienošanai E. Čoka centās veidot sakarus ar grupām citos pagastos. Partizānu komandierim izdevās nodibināt sakarus ar Naukšēnu pagastā mītošo nelegālistu grupu, kurā bija policisti Kārlis Lauberts, Jānis Bergins, vācu okupācijas laika ierēdnis Voldemārs Pētersons un leǵionārs Jānis Majors. E. Čokam radās labs iespaids gan par šĩs grupas dzīves apstākliiem, gan par tās disciplinētību salīdzinājumā ar Rūḳu mežā mītošajiem nelegālistiem. ${ }^{49}$ Jūnija sākumā E. Čoka ar sakarnieku palīdzību centās sazināties ar pusizjukušo P. Dauguḷa grupu, kura tobrīd mita Mazsalacas pagastā un par kuru izdevās uzzināt, 
jo maijā P. Dauguḷa grupu atstāja un E. Čokam pievienojās nelegālists Haralds Vorps. Acīmredzot P. Dauguḷa grupa nebija saṇēmusi ziņu, jo uz tikšanos ar E. Čokas partizāniem norunātajā vietā Mazsalacas pagastā neieradās neviens no tās dalībniekiem. ${ }^{50}$

Problēmas E. Čokam sagādāja Rūḳu mežā dzīvojošie nelegālisti. Spriežot pēc visa, viņš bija autoritāte tikai atseviškiem grupas dalībniekiem, savukārt pārējie neuztvēra nopietni partizānu komandiera nodomus gatavoties karam, un grupā netika ievēroti elementāri drošības pasākumi. Tā kā tālāka uzturēšanās šādā kolektīvā bija riskanta, 14. jūnijā E. Čoka kopā ar J. Berginu, Nikolaju Berginu un Gvido Bērziṇu devās prom no Mazsalacas pagasta un vairs neatgriezās šajā grupā. ${ }^{51}$ Partizāni apvienojās ar nelielo grupu Naukšēnu pagastā, ar kuru E. Čoka uzturēja kontaktus. Lìdz ar atsevišk,u vietējo nelegālistu pievienošanos šîs grupas dalībnieku skaits sasniedza 12 cilvēku. ${ }^{52}$

Sākotnējā atrašanās vietā mežā, netālu no Naukšēnu pagasta dzirnavām, grupa uzturējās apmēram piecas dienas. Piektajā dienā sargpostenis pamanīja, ka tuvojas iznīcinātāju k̦ēde, un E. Čoka izlēma atstāt bīstamo vietu. Vienlaikus partizānu grupa domstarpību dēḷ sadalījās divās daḷās. E. Čoka uzskatīja, ka Naukšēnu pagasts ir jāatstāj, bet to nevēlējās daḷa citu partizānu. Tā rezultātā grupa, kurā bija E. Čoka, J. Bergins, Visvaldis Kašs un Artūrs Johansons, devās uz Rūjienas pusi, savukārt otra, kurā atradās V. Pētersons, Elmārs Ratnieks, Valdis Majors, N. Bergins un K. Lauberts, lielākoties Naukšēnu pagasta iedzīvotāji, pārvietojās dziḷāk pagasta teritorijā uz Igaunijas pusi. ${ }^{53}$ Partizāns G. Bērziṇš nolēma turpmāk slēpties viens pats. ${ }^{54}$

E. Čokas grupa nobāzējās Jeru pagasta mežos un turpmāk dzīvoja klusi, lai izvairītos no iespējamām sadursmēm ar čeku. ${ }^{55}$ Partizānu komandiera centieni izveidot vienotu bruṇotās pretošanās kustību Rūjienas apkaimē lielā mērā bija cietuši neveiksmi, jo tikai neliela dạ̣a nelegālistu bija gatavi iesaistīties partizānu darbībā un ievērot tās noteikumus, tātad piemēroties skarbam un disciplinētam, bet arī nepastāvīgam dzīvesveidam.

Ko nozīmēja šādu noteikumu neievērošana, rāda Naukšēnu pagastā palikušās grupas piemērs. Pēc atdalīšanās no E. Čokas grupas partizāni pakāpeniski izklīda savu māju tuvumā un kḷuva vieglāk atklājami. 12. augustā IeTK operatīvā grupa nogalināja E. Ratnieku, kurš bija aizgājis uz savām mājām "Ratniekiem", lai nomazgātos pirtī. ${ }^{56} 15$. septembrī mežu pārmeklēšanas laikā čekas operatīvā grupa atklāja un sagūstīja V. Pētersonu. ${ }^{57}$ Ap šo pašu laiku čekisti nogalināja arī partizānu J. Majoru. ${ }^{58}$ Pēc viņa kaimiņienes un agrākās nelegālistes Lidijas Kalcenavas atmin̄ām, J. Majoru čekisti ar vina drauga palīdzību un solījumiem, ka nekādas represijas pret vinu netiks vērstas, bija izvilinājuši no slēptuves, turpat mežā nežēlīgi spīdzinājuši un pēc tam nošāvuši. Spīdzināšanas laikā J. Majoram tika izdurtas acis un salauzti kauli. ${ }^{59}$

\section{Čekas operācija Rūḳu mežã}

Pirmie lielie čekas panākumi, iznīcinot mežos dzīvojošo bruņoto nelegālistu grupas, tika gūti neilgi pēc 1945. gada Jāṇiem, kad par mērḳi kḷuva Mazsalacas pagasta Rūḳu mežā mītošā grupa, kas bija palikusi pēc partizānu komandiera E. Čokas aiziešanas.

Saskaṇā ar kāda, visticamāk, grupā esoša nodevēja, sniegto informāciju 28. jūnijā pret to tika organizēta čekas militārā operācija, iesaistot 40 IeTK iekšlietu karaspēka karavīrus un 10 iznīcinātājus. Operāciju klātienē vadīja IeTK Valmieras apriṇķa dal̦as priekšnieks apakšpulkvedis Jānis Bergs, un tas liecina par operācijai pieškirto lielo nozīmi. ${ }^{60}$ Čeka bija labi informēta gan par bunkura atrašanās vietu, gan par iekšējo 
nometnes kārtību, jo operācijas brīdī nelegālisti gulēja diendusu. Militāro kravas automašīnu pārvietošanos meža virzienā pamanīja vietējie iedzīvotāji, taču neviens nebrīdināja mežā esošos cilvēkus.

Guḷošos nelegālistus uzmodināja pie bunkura nomesta granāta, kas nesprāga. Visi grupas locekḷi uzrāvās augšā un panikā metās bēgt, nepaṇēmuši ieročus, kuri bija turpat bunkurā. Čekistiem atklājot uguni, tika nogalināts Voldemārs Krūmiņš, savukārt Kārlis Grīnbergs, bēgot Igaunijas virzienā, uzskrēja virsū čekistu k,ēdei un tika sagūstīts. Citiem izdevās aizbēgt, pateicoties tam, ka, neievērojot iepriekšējo norunu, vini skrēja citos virzienos, kurus karavīri nebija nobloḳejuš̌i. Bēgšanas laikā kājā tika ievainots Jānis Nāzars, bet viṇam ar sievu izdevās atrauties no vajātājiem. ${ }^{61}$

Aizbēgušie nelegālisti sadalījās, un nelielā grupa bija izjukusi. 1945. gada 10. augustā bijušie grupas dalībnieki J. Rezgalis un E. Blāķis tika notverti E. Blāḳa mājās Ternejas pagasta "Kurpniekos". ${ }^{62}$ Operācijas rezultātā čekistiem izdevās noskaidrot arī vairākus grupas atbalstītājus, kuri tika arestēti vai piespiesti sadarboties, kā, piemēram, mežsargu E. Vīḳi, pēc kura sniegtajām ziṇām 1945. gada 19. septembrī tika aizturēts H. Vorps. ${ }^{63}$

Veiktā operācija iezīmēja sākumu nopietniem čekistu centieniem likvidēt mežā dzīvojošās nelegālistu grupas, tomēr, nenemot vērā gūtos rezultātus un iespēju padižoties vadībai, faktiskie čekas panākumi bija maznozīmīgi, jo triecienam tika pakḷauts bariņš nelegālistu, kuri negatavojās cīnīties pret okupantiem. E. Čokas vadītais atzars bija savlaicīgi paglābies no nelaimes.

\section{Skujiṇa grupas pirmie zaudējumi un konspirēšanās}

1945. gada septembris Skujina grupai iesākās diezgan pārliecinoši, jo tā ar savu darbību bija pakḷāvusi bailēm vietējos aktīvistus, tādēl IeTK Valmieras apriṇķa daḷa nopietni pievērsās Katvaru pagastam. 26. oktobrī tika izstrādāts operatīvais plāns un aǵentūras lieta Terroristi Skujiņa grupas iznīcināšanai. ${ }^{64}$ Aktīvi tika sākts pārmeklēt Katvaru pagasta mežus un viensētas, lai notvertu partizānus un vinu atbalstītājus, kā arī nopietnāks darbs pie aǵgentūras veidošanas šajā apkaimē. Laikā no 27. līdz 29. oktobrim IeTK Valmieras aprinķa dalas priekšnieka J. Berga vadībā Katvaru pagastā tika organizēta operācija partizānu meklēšanai, kurā tika iesaistīti iekšlietu karaspēka karavīri un iznīcinātāju bataljona kaujinieki - kopumā 70 cilvēki. ${ }^{65}$

Pirmie plāna rezultāti sekoja uzreiz. 28. oktobrī partizāni E. un A. Skujiṇi pa ceḷam uz kādu balli ielauzās "Līdumniekos" pie aktīvistes Z. Kalniņas, lai nolaupītu pārtiku. ${ }^{66}$ Pēc iziešanas no mājas abi brāḷi pagalmā uzdūrās čekistu vienībai, kura, iespējams, bija izsekojusi partizānus pēc pēdām. Bezcerīgā situācijā Skujiņi centās pretoties vairākiem desmitiem pretinieka karavīru klajā laukā. Čekistiem atklājot uguni, E. Skujiņš tika nogalināts uzreiz, savukārt ievainotais A. Skujinš̌ paguva uzspridzināties ar rokasgranātu. Trīs dienu laikā tika aizturēti arī par partizānu atbalstīšanu aizdomās turētie 22 cilvēki un kāds nelegālists Jānis Papēdis. ${ }^{67}$ Veiktā operācija iezīmēja beigas salīdzinoši brīvajai un bezrūpīgajai partizānu darbībai Katvaru pagastā.

Abu grupas biedru nogalināšana un daudzo atbalstītāju aresti radīja Skujiṇa grupā nopietnu satraukumu par tālāko nākotni. Legalizēties nolēma grupas dalībnieks Jānis Oškājs, kurš pieteicās varas iestādēm 11. novembrī. Šo apstākli centās izmantot čekisti, kuri gan J. Oškāju, gan viņa māti Annu Ozoliṇu piespieda kḷūt par slepenajiem ziņotājiem "Salmiņš" un "A. Kalniņš” ar uzdevumu izspiegot Skujiņa grupu. Abi savervētie gan netaisījās 
nodot partizānus, un J. Oškājs drīz vien izbrauca no Valmieras apriņķa. ${ }^{68}$

Tā kā Katvaru pagastā bija kḷuvis bīstami uzturēties regulāro meža pārmeklēšanu dēḷ, Skujiņa grupa nolēma mainīt atrašanās vietu un pārziemot ārpus pagasta. Novembra beigās grupas partizāni pārgāja uz Viḷkenes pagastu pie grupas atbalstītājas Nanijas Lesiņas, un netālu no vinas mājas Rustūžu purvā grupa uzcēla bunkuru pārziemošanai. Grupai pievienojās arī V. Skujiņa draudzene Elza Kurpniece, par kuru saistībā ar viṇas sakariem ar partizāniem bija sākusi interesēties čeka. ${ }^{69}$ Grupa mierīgi ieziemojās Rustūžu purvā, un Skujiņa grupas darbībā iestājās klusuma periods.

\section{Secinājumi}

Līdzīgi kā citviet Latvijā, Ziemeḷrietumvidzemē pēc padomju okupācijas atjaunošanās izvērstās mobilizācijas un represiju dēḷ sākās personu pāriešana nelegālā stāvoklī un mežos veidojās brunotu nelegālistu grupas, kas bija pamats tālākajai partizānu grupu izveidei. Kopumā šādās grupās Ziemeḷrietumvidzemē apvienojās aptuveni 83 cilvēki, tajā pašā laikā jāatzīmē, ka pētījumā nav aplūkotas visas bruṇotās nelegālistu grupas. Pieḷaujams, ka lielākās un mazākās grupās atradās nedaudz vairāk kā 100 cilvēki, kas bija samērā neliels skaits uz citu Latvijas reg̣ionu fona.

Nacionālo partizānu grupu veidošanās norisinājās no 1944. gada rudens līdz 1945. gada pavasarim. Ziemeḷrietumvidzemē izveidojušās nelielās partizānu grupas pārsvarā gan bija pasīvas, ieturot nogaidī̌̌anas taktiku cerībā uz Rietumvalstu un PSRS karu, kas l̦autu cīnīties par Latvijas neatkarību. Līdz tam prioritāte bija dzīvības saglabāšana, jo uzbrukumi okupācijas režīmam izraisītu tā pretdarbību un zaudējumus partizāniem. Salīdzinājumā ar Latvijas reǵioniem, kur partizānu aktivitāte bija ievērojami plašāka, iespējams, liela loma bija arī lielajai grupu izkliedētībai, līdz ar to partizāni nejuta sevi kā pietiekami lielu spēku iepretī okupantiem, lai sāktu uzbrukumus. Citas grupas nekḷuva par ko vairāk kā bruṇotiem nelegālistu bariniem, jo nebija motivētas cīnìties pret padomju režīmu.

Tādējādi partizānu darbības rezultāti šajā reǵionā bija pieticīgi. Okupācijas režīms Ziemeḷrietumvidzemē 1945. gadā zaudēja piecus cilvēkus, kuri krita Skujiņa grupas aktīvās darbības dēḷ. Tā kā partizānu skaitliskais sastāvs nebija liels, uzbrukumi tika veikti tikai individuāliem padomju aktīvistiem. İstenot plašākus uzbrukumus, piemēram, pagastu centriem, partizāni nemēgināja, tāpēc okupācijas režīma pārvaldes aparāta veidošanos un darbību partizānu uzbrukumi būtiski neietekmēja.

Sākot ar 1945. gada vasaru, IeTK uzsāka aktīvus pasākumus bruṇoto grupu likvidācijai mežos. Partizānu tuvākās atbalsta bāzes, tas ir, mājās palikušo radinieku, aresti un terorizēšana deva rezultātu, un, sākot ar 1945. gada vasaru, legalizējās daudzi partizāni un nelegālisti, kuri nebija paspējuši nopietni "noziegties" padomju varas priekšā. 1945. gadā kopumā no aplūkotajām grupām legalizējās 31 persona, tas bija aptuveni $37 \%$ no mežos dzivojošo grupu sastāva.

Vienlaikus okupācijas režīms veica arī militāras operācijas bruņotās pagrīdes likvidācijai. To laikā 1945. gadā Ziemeḷrietumvidzemē gāja bojā septini un tika sagūstīti 14 partizāni un nelegālisti. Gandrīz visi zaudējumi tika ciesti čekas operācijās - tas lielākoties bija pašu partizānu un nelegālistu meža dzīves pieredzes trūkuma, paviršas attieksmes pret konspirāciju un pārāk lielas pašpārliecinātības rezultāts. 1945. gada nogali sagaidīja tikai divas partizānu grupas, kuras spēja droši ieziemoties tālāk no agrākajām darbības vietām, tādējādi uz laiku pazūdot no padomju drošǐbas iestāžu redzesloka. 


\section{ATSAUCES UN SKAIDROJUMI}

${ }^{1}$ Ar Ziemeḷrietumvidzemi rakstā tiek saprasta Valmieras apriņ̧̧a ziemeḷrietumu dạla, saskaṇā ar 1945. gada teritoriāli administratīvo iedalījumu tajā ietilpa Katvaru, Pociema, Alojas, Ainažu, Mazsalacas, Rozēnu, Rūjienas, Idus, Naukšēnu, Viḷ̣enes, Pāles, Puikules, Ipiḳu, Sēḷu, Umurgas un Jeru pagasts.

${ }^{2}$ HEINRIHS StRodS. Latvijas nacionālo partizānu karš, 1944-1956. Rīga 2012, 11.-15. lpp.

${ }^{3}$ ZIGMĀRS TURČINSKIS. Ziemeḷvidzemes mežabrāḷi. Latvijas nacionālo partizānu cīṇas Valkas apriṇkī un Alūksnes aprink, ziemeḷu daḷā. 1944.-1953. gads. Rīga 2011, 63. lpp.

${ }^{4}$ ZIGMĀRS TURČINSKIS. Karš pēc kara: Latvijas nacionālo partizānu cīṇas 20. gadsimta 40. gadu beigās - 50. gadu sākumā. In: HEINRIHS STRODS (sast.). Karš pēc kara, 1944-1956. Rīga 2007, 100. lpp.

${ }^{5}$ TURČINSKIS, Ziemel̦vidzemes mežabrāḷi, 136. lpp.

${ }^{6}$ TURČINSKIS, Karš pēc kara, 102.-104. lpp.

7 TURČINSKIs, Ziemel̦vidzemes mežabrāli, 399 lpp.

${ }^{8}$ RAITIS ĀBELNIEKS, AigARS URTĀNS. Nacionālā pretošanās kustība un padomju okupācijas represīvo iestāžu pretdarbība Bauskas apriņ̧īirajonā. In: DZINTARS ĒRgLIS (sast.). Okupētā Latvija 1940-1990 / Occupied Latvia 1940-1990. Rīga 2007 (Latvijas vēsturnieku komisijas raksti, 19), 356.-407. lpp.

${ }^{9}$ Ibidem, 170.-171., 182., 253. lpp.

${ }^{10}$ Latvijas PSR VDK par sevišķi bīstamiem pretvalstiskiem noziegumiem apsūdzēto personu krimināllietas. Latvijas Nacionālais arhīvs, Latvijas Valsts arhīvs, Rīga (turpmāk - LNA LVA), 1986-1-2.

${ }^{11}$ Dokumenti par Latvijas PSR VDK cīņu pret nacionālo pagrīdi, 1944-1956. Ibidem, 1825-2.

${ }_{12}$ PSRS drošības dienesta Viskrievijas Ārkārtas komisijas (VĀK) apzīmējums, kas radies no tās saīsinājuma krievu valodā un vēlāk piemērots VĀK pēctečiem. Faktiski tas tika oficiāli izmantots čekas lietvedībā.

13 JURIS SĀRnIS. Pieviltie. Cesvaine 2015, 103 lpp.; Lidija Kalcenava. In: SANITA BĒRZIN̦A-REINSONE (sast.). Meža meitas: 12 sievietes par dzīvi mājās, mežāâ, cietumā. Rīga 2015, 289.-319. lpp.; MARTA GRĪNVALDE. Cilvēki un likteņi. In: ALEKSANDRS KALVĀNS (sast.). Uz ežiņas galvu liku. Rīga 1993, 232.-244. lpp.

${ }^{14}$ LPSR kara komisariāta sarakste ar apriņ̧̧u kara komisariātiem un ziņojumi par mobilizāciju Sarkanajā armijā, 1944. LNA LVA, 1248-2-2, 373. lp.

15 JĀNIS RIEKSTIN̦Š. Latvijas iedzīvotāju mobilizācija Sarkanajā armijā. In: DzINTARS ĒRgLIS (sast.). Okupētā Latvija 20. gadsimta 40. gados / Occupied Latvija in 20 ${ }^{\text {th }}$ Century (1940-s). Rīga 2005 (Latvijas Vēsturnieku komisijas raksti, 16), 437. lpp.

${ }^{16}$ Komunistiskās (boḷ̌eviku) Partijas apriṇķa un pilsētu komiteju atskaites par kara daḷu darbu, 1945. LNA LVA, 101-8-17, 31. lp.

${ }^{17}$ Sarakste par Valsts drošības ministrijas, Iekšlietu ministrijas un milicijas iestāžu darbu, 1945. Ibidem, PA-101-8-19, 32. lp.

${ }^{18}$ GRĪNVALDE, Cilvēki un likten,i, 233.-234. lpp.

${ }^{19}$ K. Lauberta krimināllieta, 1950. LNA LVA, 1986-1-4916, 77. lp.

${ }^{20}$ TURČINSKIs, Ziemel̦vidzemes mežabrāli, 26. lpp.

${ }^{21}$ Legalizētā bandīta Ernesta Viḷna gimenes deportācijas lieta, 1949. LNA LVA, 1894-Limbažu aprinkisis-1656, 3. lp.

${ }^{22}$ Ernesta Korpa krimināllieta, 1950. Ibidem, 1986-1-4061, 218. lp.

${ }^{23}$ Kartotēka. Sadaḷa "Latvijas PSR VDM Valmieras aprinķa daḷas dienesta, informatīvie un specziņojumi par veiktajām operācijām pret nacionālajiem partizāniem”. Ibidem, 1825-2-165, 3. lp. 
${ }^{24}$ Kartotēka. Sadaḷa "Latvijas PSR VDM Valmieras apriṇķa daḷas veiktās kaujas operācijas pret nacionālajiem partizāniem". Ibidem, 1825-2-168, 10. lp.

${ }^{25}$ Legalizētā bandīta Ernesta Viḷna gímenes deportācijas lieta, 1949. Ibidem, 1894-Limbažu aprinkisis-1656, 3.-4. lp.

${ }^{26}$ Ernesta Korpa krimināllieta, 1950. Ibidem, 1986-1-4061, 23. lp.

${ }^{27}$ Legalizētā bandīta Ernesta Viḷna g̣imenes deportācijas lieta, 1949. Ibidem, 1894-Limbažu aprinkisis-1656, 34. lp.

${ }^{28}$ Jāṇa Ilus krimināllieta, 1945. Ibidem, 1986-1-17186, 107., 109., 113. lp.

${ }^{29}$ Ibidem, 31. lp.

${ }^{30}$ Kartotēka. Sadaḷa "Latvijas PSR VDM Valmieras apriņ,̧a daḷas veiktās kaujas operācijas pret nacionālajiem partizāniem". Ibidem, 1825-2-168, 4. lp.

${ }^{31}$ SĀRNIS, Pieviltie, 103. lpp.

${ }^{32}$ Kartotēka. Sadaḷa "Latvijas PSR VDM Valmieras aprinķa daḷas dienesta, informatīvie un specziņojumi par veiktajām operācijām pret nacionālajiem partizāniem”. LNA LVA, 1825-2-165, 2. lp.

${ }^{33}$ Pētera Dauguḷa krimināllieta, 1945. Ibidem, 1986-1-36139, 22. lp.

${ }^{34}$ Ibidem, 3., 94. lp.; SĀRNIS, Pieviltie, 100. lp.

${ }^{35}$ Viḷa Skujiṇa krimināllieta, 1948. LNA LVA, 1986-1-40698, 1. sēj., 171. lp.

${ }^{36}$ Ibidem, 118. lp., 4. sēj., 126., 171. lp.

37 Ērika Skujiņa atmiņas, pierakstītas 2016. gada augustā. Autora arhīvs.

${ }^{38}$ Kartotēka. Sadaḷa "Nacionālo partizānu aktivitātes Valmieras apriṇkī”. LNA LVA, 1825-2-167, 10. lp.

${ }^{39}$ Viḷa Skujiṇa krimināllieta, 1948. Ibidem, 1986-1-40698, 4. sēj., 308. lp.

${ }^{40}$ Kartotēka. Sadaḷa "Latvijas PSR VDM Valmieras apriṇķa daḷas veiktās kaujas operācijas pret nacionālajiem partizāniem”. Ibidem, 1825-2-168, 20. lp.

${ }^{41}$ Vị̣a Skujiṇa krimināllieta, 1948. Ibidem, 1986-1-40698, 4. sēj., 129., 292. lp.

${ }^{42}$ Ibidem, 1. sēj., 20. lp.

${ }^{43}$ Komunistiskās (bolševiku) Partijas apriṇka un pilsētu komiteju atskaites par kara daḷu darbu, 1945. Ibidem, 101-8-17, 251. lp.

${ }^{44}$ Kartotēka. Sadaḷa "Latvijas PSR VDM Valmieras aprinķa daḷas dienesta, informatīvie un specziņojumi par veiktajām operācijām pret nacionālajiem partizāniem”. Ibidem, 1825-2-165, 40. lp.

${ }^{45}$ K. Lauberta krimināllieta, 1950. Ibidem, 1986-1-4916, 77. lp.

${ }^{46}$ Kārḷa Grīnberga krimināllieta, 1945. Ibidem, 1986-1-17559, 1. sēj., 72., 80. lp.

${ }^{47}$ K. Lauberta krimināllieta, 1950. Ibidem, 1986-1-4916, 24., 72., 80., 182. lp.

${ }^{48}$ Kārḷa Grīnberga krimināllieta, 1945. Ibidem, 1986-1-17559, 1. sēj., 109., 131.-132., 194.-195. lp.

${ }^{49}$ Ibidem, 73., 181. lp.

${ }^{50}$ Ibidem, 124.-125. lp.

${ }^{51}$ K. Lauberta krimināllieta, 1950. Ibidem, 1986-1-4916, 78. lp.

${ }^{52}$ Ibidem, 94. 1p.

${ }^{53}$ Artura Johansona krimināllieta, 1948. Ibidem, 1986-1-38788, 37. lp.

${ }^{54}$ K. Lauberta krimināllieta, 1950. Ibidem, 1986-1-4916, 78. lp.

${ }^{55}$ Artura Johansona krimināllieta, 1948. Ibidem, 1986-1-38788, 38. lp.

${ }^{56}$ Kartotēka. Sadaḷa "Nacionālie partizāni”. Ibidem, 1825-2-4, 1293. lp.

${ }^{57}$ Kartotēka. Sadaḷa "Latvijas PSR VDM Valmieras apriṇķa daḷas veiktās kaujas operācijas pret nacionālajiem partizāniem”. Ibidem, 1825-2-168, 29. lp. 
${ }^{58}$ Kartotēka. Sadaḷa “Nacionālie partizāni”. Ibidem, 1825-2-4, 24. lp.

${ }^{59}$ Lidija Kalcenava. Sk.: BĒRZIŅA-REInSONE, Meža meitas, 297. lpp.

${ }^{60}$ Kartotēka. Sadala "Latvijas PSR VDM Valmieras apriṇķa daḷas veiktās kaujas operācijas pret nacionālajiem partizāniem". LNA LVA, 1825-2-168.

${ }^{61}$ GRînVALDE, Cilvēki un likteñi, 239., 240., 244. lpp.

${ }^{62}$ Kārḷa Grīnberga krimināllieta, 1945. LNA LVA, 1986-1-17559, 1. sēj., 107., 109., 163. lp.

${ }^{63}$ Ibidem, 25. 1p.

${ }^{64}$ Kartotēka. Sadaḷa "Latvijas PSR VDM Valmieras aprinķa daļas dienesta, informatīvie un specziņojumi par veiktajām operācijām pret nacionālajiem partizāniem”. Ibidem, 1825-2-165, 37. lp.

${ }^{65}$ Kartotēka. Sadaḷa "Latvijas PSR VDM Valmieras apriņ̧̣a daḷas veiktās kaujas operācijas pret nacionālajiem partizāniem". Ibidem, 1825-2-168, 33. lp.

${ }^{66}$ Viḷa Skujiṇa krimināllieta, 1948. Ibidem, 1986-1-40698, 4. sēj., 214. lp.

${ }^{67}$ Kartotēka. Sadaḷa "Latvijas PSR VDM Valmieras apriṇķa daḷas veiktās kaujas operācijas pret nacionālajiem partizāniem”. Ibidem, 1825-2-168, 33. lp.

${ }^{68}$ Annas Ozolinas krimināllieta, 1948. Ibidem, 1986-1-29203, 56. lp.

${ }^{69}$ Viḷa Skujiṇa krimināllieta, 1948. Ibidem, 1986-1-40698, 1. sēj., 118.-119. lp.

\section{SUMMARY}

The Soviet-issued mobilization soon after the reoccupation of Valmiera district was the reason why many fled into forests to avoid mobilization by the Red Army. At the same time, the Soviets began to arrest the former German occupation regime officials, policemen, members of different organizations labelled as "fascist", etc., so another wave of people sought refuge in the forests. These people formed armed groups, which served as the basis for the armed resistance against the Soviet occupation regime. Approximately 83 people were in these groups, but the total number of persons in bigger or smaller armed groups hiding in Northwestern Vidzeme in 1945 probably was slightly over 100, which was quite low in comparison to the other regions of Latvia.

The first partisan groups became active during May 1945, but most of the groups in Northwestern Vidzeme kept a low profile and waited for a possible war between the Soviet Union and the West. Some groups did not develop into armed resistance groups at all, and kept on living in the forests as illegals without particular plans for the future.

From the summer of 1945, the partisans began their first attacks, but the only one to attack the Soviets was the group of Vilis Skujinš that operated north of Limbaži, in Katvaru parish. This group managed to kill 5 Soviet activists and the attacks, with the exception of two activists being killed in a Soviet raid on Skujinš group, were carried out on individual persons. Larger scale operations were difficult to accomplish, because the group of Skujiņš was small - until October 1945, it had only six active members who operated individually or in pairs. Consequently, the Soviet authority over the area remained unchallenged. Partisan activity here had more of a psychological effect on local Soviet activists who expected to be targeted by partisans.

Starting from the summer of 1945 , some of the illegals and partisan groups began to dissolve as their relatives at home were being harassed by the Cheka. These groups were also vulnerable to attacks by the Soviet security forces, as they lacked basic discipline and secrecy needed to survive. During 1945, the Cheka managed to kill 7 and capture 
14 partisans and illegals in Northwestern Vidzeme. Amnesty campaign was launched, promising illegals a chance to continue their normal lives. It was very effective, as approximately $37 \%$ of these persons surrendered to Soviet authorities until the end of 1945.

In the autumn of 1945, only two partisan groups remained in Northwestern Vidzeme. Because of being able to adapt to the new challenges posed by the Soviet security forces, partisan groups survived until the end of 1945. These groups prepared for the winter and ceased any activities that could endanger them during this difficult period. 